\title{
Effectiveness of extracorporeal blood purification (hemoadsorption) in patients with severe coronavirus disease 2019 (COVID-19)
}

Masoumeh Asgharpour ${ }^{1} \mathbb{B}$, Hamed Mehdinezhad ${ }^{1} \mathbb{D}$, Masoumeh Bayani² $\mathbb{D}$, Mahmoud Sadeghi Haddad Zavareh ${ }^{2}$, Seyed Hossein Hamidi ${ }^{3} \mathbb{B}$, Roghayeh Akbari ${ }^{4} \mathbb{B}$, Reza Ghadimi ${ }^{5}$, Ali Bijani ${ }^{5}$ and aimin Mouodi ${ }^{*}$ (D)

\begin{abstract}
Background: Extracorporeal blood purification has been proposed as one of the therapeutic approaches in patients with coronavirus infection, because of its beneficial impact on elimination of inflammatory cytokines.

Methods: This controlled trial has been conducted on critically ill COVID-19 patients admitted in the state hospital affiliated to Babol University of Medical Sciences, Iran who received different antiviral and antibacterial drugs, and different modalities of respiratory treatments and did not have positive clinical improvement. No randomization and blindness was considered. All of the participants underwent three sessions of resin-directed hemoperfusion using continuous renal replacement therapy with a mode of continuous venovenous hemofiltration (CWH).
\end{abstract}

Results: Five men and five women with a mean age of $57.30 \pm 18.07$ years have been enrolled in the study; and six of them have improved after the intervention. Peripheral capillary oxygen saturation (SpO2) changed after each session. Mean SpO2 before the three sessions of hemoperfusion was $89.60 \% \pm 3.94 \%$ and increased to $92.13 \% \pm$ $3.28 \%$ after them $(p<0.001)$. Serum IL-6 showed a reduction from $139.70 \pm 105.62$ to $72.06 \pm 65.87 \mathrm{pg} / \mathrm{mL}(p=$ $0.073)$; and c-reactive protein decreased from $136.25 \pm 84.39$ to $78.25 \pm 38.67 \mathrm{mg} / \mathrm{L}(P=0.016)$.

Conclusions: Extracorporeal hemoadsorption could improve the general condition in most of recruited patients with severe coronavirus disease; however, large prospective multicenter trials in carefully selected patients are needed to definitely evaluate the efficacy of hemoperfusion in COVID-19 patients.

Trial registration: The research protocol has been registered in the website of Iranian Registry of Clinical Trials with the reference number IRCT20150704023055N2.

Keywords: Coronavirus infection, Extracorporeal dialysis, Critical illness

\footnotetext{
*Correspondence: dr.mouodi@gmail.com

${ }^{5}$ Social Determinants of Health Research Center, Health Research Institute, Babol University of Medical Sciences, Ganjafrooz Street, Babol, Iran

Full list of author information is available at the end of the article
}

C C The Author(s). 2020 Open Access This article is licensed under a Creative Commons Attribution 4.0 International License, which permits use, sharing, adaptation, distribution and reproduction in any medium or format, as long as you give appropriate credit to the original author(s) and the source, provide a link to the Creative Commons licence, and indicate if changes were made. The images or other third party material in this article are included in the article's Creative Commons licence, unless indicated otherwise in a credit line to the material. If material is not included in the article's Creative Commons licence and your intended use is not permitted by statutory regulation or exceeds the permitted use, you will need to obtain permission directly from the copyright holder. To view a copy of this licence, visit http://creativecommons.org/licenses/by/4.0/ The Creative Commons Public Domain Dedication waiver (http://creativecommons.org/publicdomain/zero/1.0/) applies to the data made available in this article, unless otherwise stated in a credit line to the data. 


\section{Background}

Corona viruses are a large family of viruses that can lead to a wide range of diseases; from a simple common cold to severe health problems that have attracted much attention in the world, such as the Middle East Respiratory Syndrome (MERS-CoV) and Severe Acute Respiratory Syndrome (SARS) [1]. Corona virus disease 2019 (COVID-19) is a new strain of this viral family that was first introduced in China in 2019 and has never been seen in human populations before [2, 3]. According to the World Health Organization, a total of 1,773,084 confirmed cases and 111,652 deaths have been reported worldwide until April 132,020; of these, 99,713 confirmed and 5107 deaths were from the Eastern Mediterranean Region [4].

Different clinical features have been reported for COVID-19 so far, from an asymptomatic form to a severe disease leading to respiratory failure requiring intensive-care treatment and mechanical ventilation, multiple organ involvement and even multiple organ failure [5]. Common manifestations of confirmed cases have been listed as fever, fatigue, dry cough, nasal congestion, shortness of breath, myalgia and arthralgia with laboratory findings such as lymphopenia, high plasma levels of c-reactive protein, and elevated lactate dehydrogenase; $7-10 \%$ of patients may progress to critical cases; and about $1-2 \%$ of cases will result in death; of course, the mortality rate of patients varies according to their geographical location [3].

Similar to other outbreaks caused by new viral agents, a definite approved treatment has not yet been introduced, and treatment protocols presented in scientific evidence are all symptomatic and supportive [3, 5]. Patients who develop acute respiratory distress syndrome are more likely to require ICU care and die, and the cytokine storm has been found to be associated with the severity of the disease [6]. It has been demonstrated that at the beginning of sepsis process, the overshoot of multiple pro-inflammatory mediators is frequently observed, and patient mortality will be much higher when the serum level of pro-inflammatory and anti-inflammatory cytokines is considerable $[6,7]$. Blocking the overshoot of these inflammatory mediators can stop the sepsis process and improve patient outcomes [7]. One of the treatment approaches that can be taken to reduce these cytokines is extracorporeal blood purification, also referred to as hemoperfusion [8-11]. Hemoperfusion is an extracorporeal technique involving the passage of blood through a cartridge where solutes are removed by direct binding to the sorbent material. Hemoperfusion acts by adsorption mechanism, related to different cartridges which have been provided in its structure. It differs from hemodialysis because hemodialysis acts by diffusion mechanism. In continuous venovenous hemofiltration
(CVVH) mode of hemoperfusion, the mechanism of convection is added, and no diffusion is occurred [12]. The effectiveness of hemoperfusion on serum level of IL-6, IL-8, IL-1 $\beta$, and tumor necrosis factor has been demonstrated in some previous studies [13]. Four extracorporeal therapies have been introduced for cytokine removal in patients with COVID-19: continuous renal replacement therapy (CRRT) with hollow fibre filters with adsorptive properties; direct hemoperfusion using a neutromacroporous sorbent; plasma adsorption on a resin after plasma separation from the whole blood; and high-dose CRRT with medium or high cut-off membranes [10].

Considering the association of increased cytokines release with severity of COVID-19 disease, and the effect of hemoperfusion on removal of these cytokines [7, 13], this study conducted to determine the effectiveness of hemoperfusion in patients with severe coronavirus disease 2019.

\section{Methods}

This controlled trial has been performed on adult patients (aged 18 years and over) with severe COVID-19 disease admitted in the state hospital affiliated to Babol University of Medical sciences, Iran; since 2020/03/10 to 2020/03/23. Patients who had clinical manifestations of COVID-19 in addition to positive radiographic (lung CT-scan) findings or laboratory confirmation by testing of the oropharyngeal specimen, using real-time polymerase chain reaction were included, if they had one of these criteria: individuals who had partial pressure of oxygen in alveoli (PaO2) less than $60 \mathrm{mmHg}$, even after different methods of oxygen-therapy; or peripheral capillary oxygen saturation ( $\mathrm{SpO} 2$ ) less than $88 \%$ with no clinical improvement despite $48 \mathrm{~h}$ of non-invasive respiratory therapy. The individuals recruited in the research when the informed consent was obtained. Exclusion criteria were plasma platelet count less than 30,000 per microliter, and multiple organ dysfunction.

The patients underwent extracorporeal blood purification on three sessions [10], using continuous renal replacement therapy (CRRT) machine manufactured by the B. Braun Company, Germany, with a mode of continuous venovenous hemofiltration. Jugular temporary catheter (Bard trademark) was placed by a vascular surgeon. Heparin has been injected as an anticoagulant agent throughout the CRRT by the arterial line depending on the patient's coagulation status [14]. The blood flow rate (QB) was $200-250 \mathrm{~mL} /$ minute, the hemofiltration fluid flow rate (QD) 2Lit/hour, and the effluent volume was 2lit/hour. During the CRRT procedure, the fluid outflow from the patient was adjusted as the same amount of the fluid input.

Each session conducted in $14-18 \mathrm{~h}$ per day; the first 4-6 h with CRRT plus hemoperfusion; and the last 10$12 \mathrm{~h}$ with CRRT alone. We used resin-directed 
hemoadsorption cartridges (HA-280 and HA-230) manufactured by the Jafron Biomedical Company, China. The second course of hemoperfusion was performed 24-48 $\mathrm{h}$ after the first and the third session $24-48 \mathrm{~h}$ after the second time. Since the patients with severe coronavirus disease have been enrolled in the study, neither control group nor randomisation was considered. Antiinflammatory and antiviral medications have been controlled and patients who had nearly similar treatment conditions were included in the study.

Age, gender, duration of hospital and ICU admission due to COVID-19, comorbid disorders, medications received for the recent disease; vital signs including body temperature, pulse rate, blood pressure, and respiratory rate; laboratory tests including plasma white blood cell count, hemoglobin, plasma platelet count, serum creatinine, blood urea nitrogen, serum c-reactive protein and lactate dehydrogenase, hepatobiliary function tests (AST, $\mathrm{ALT}$, and total and direct bilirubin); and $\mathrm{SpO} 2$ have been recorded in the research data sheet. In addition to, the mode of oxygen therapy has been recorded before and after each session of the hemoperfusion.

Primary outcome was improving the general condition based on the patient's assessment 1 week after the third session of hemoperfusion compared to the initial clinical condition before the first hemoperfusion. The patient was considered as improved if he did not need to receive any intensive respiratory treatment, based on the status of peripheral capillary oxygen saturation. Furthermore, the serum level of interleukin-6 (IL-6) has been measured as the secondary outcome of the study [15].

Required clinical criteria used to determine the patient's readiness for weaning from mechanical ventilation included: improvement of the cause of the respiratory failure; hemodynamic stability; $\mathrm{PaO} 2 / \mathrm{FiO} 2 \geq 150$ or $\mathrm{SpO} 2 \geq 90 \%$ on $\mathrm{FiO} 2 \leq 40 \%$ and positive end-respiratory pressure $\leq 5 \mathrm{cmH} 2 \mathrm{O} ; \mathrm{PH}>7.25$ and able to initiate an inspiratory effort [16].

Data analysis was performed using SPSS-18 software package. Paired t-test was used to assess $\mathrm{SpO} 2$ in each patient, before and after the intervention; and t-test was used to analyze the examined demographic variables. To compare inflammatory variables which did not have normal distributions, Wilcoxon signed ranks test and Mann-Whitney test were used.

This clinical trial adheres to CONSORT guidelines. A completed CONSORT checklist has been provided as Appendix 1.

This research has been approved by the Ethics Committee of Babol University of Medical Sciences with the approval code IR.MUBABOL.HRI.REC.1399.038. Also, the research protocol has been registered in the website of Iranian Registry of Clinical Trials with the reference number IRCT20150704023055N2.

\section{Results}

Ten critically ill COVID-19 patients with a mean age of $57.30 \pm 18.07$ (a range from 26 to 83 ) years have been enrolled in the study. The flow diagram of the participants has been presented in Fig. 1. Five of them (50.0\%) were male and five $(50.0 \%)$ were female. The hemoperfusion treatment was started in patients $1-8$ (average 4.7) days after the hospitalization. In one patient the second course of hemoperfusion was conducted 4 days after the first, because of some difficulties in providing the hemoperfusion cartridges; and others underwent the intervention according to the planned program.

Baseline characteristics of the participants have been presented in Table 1; laboratory measures before the first and the third session of hemoperfusion, and the treatment outcome have been summarized in Table 2 . Six of the ten enrolled patients have been improved. The measured IL-6 mean serum level before the intervention was $139.70 \pm 105.62 \mathrm{pg} / \mathrm{mL}$ and decreased to $72.06 \pm 65.87$ after the third session of hemoperfusion $(p=0.073)$. Mean serum level of c-reactive protein before and after the intervention was $136.25 \pm 84.39$ and $78.25 \pm 38.67 \mathrm{mg} / \mathrm{L}$, respectively $(P=0.016)$. Laboratory measures of the two expired and improved groups have been compared in Table 3. The percentage of plasma lymphocytes had a statistically significant difference between the two groups, the patients who have not been improved showed a lower plasma lymphocytes count $(p=0.038)$.

Peripheral capillary oxygen saturations before and after each session of hemoperfusion have been showed in Fig. 2. Mean $\mathrm{SpO} 2$ value was $89.60 \pm 3.94 \%$ before the three sessions of intervention and increased to $92.13 \pm$ $3.28 \%$ after the hemoperfusion $(p<0.001)$. The change of $\mathrm{SpO} 2$ had no significant difference in patients receiving different modes of oxygen therapy $(p=0.313)$.

\section{Discussion}

Our results showed that three sessions of extracorporeal hemoadsorption could improve the peripheral capillary oxygen saturation in six of the ten critically ill patients with COVID-19 disease. Mean SpO2 showed a significant improvement after the intervention.

Different aspects have been listed as the potential mechanisms of organ damage and disease severity in COVID-19 patients. One of the most important mechanisms is cytokine release syndrome (also known as cytokine storm) [17-19]; and IL-6 has been represented as the most important causative cytokine in cytokine storm $[10,19]$. The COVID-19 disease progresses rapidly when the cytokine storm occurs and immune responses increase [17]. Extracorporeal blood purification has been proposed as one of the treatment approaches to remove these inflammatory cytokines and could potentially be beneficial in 


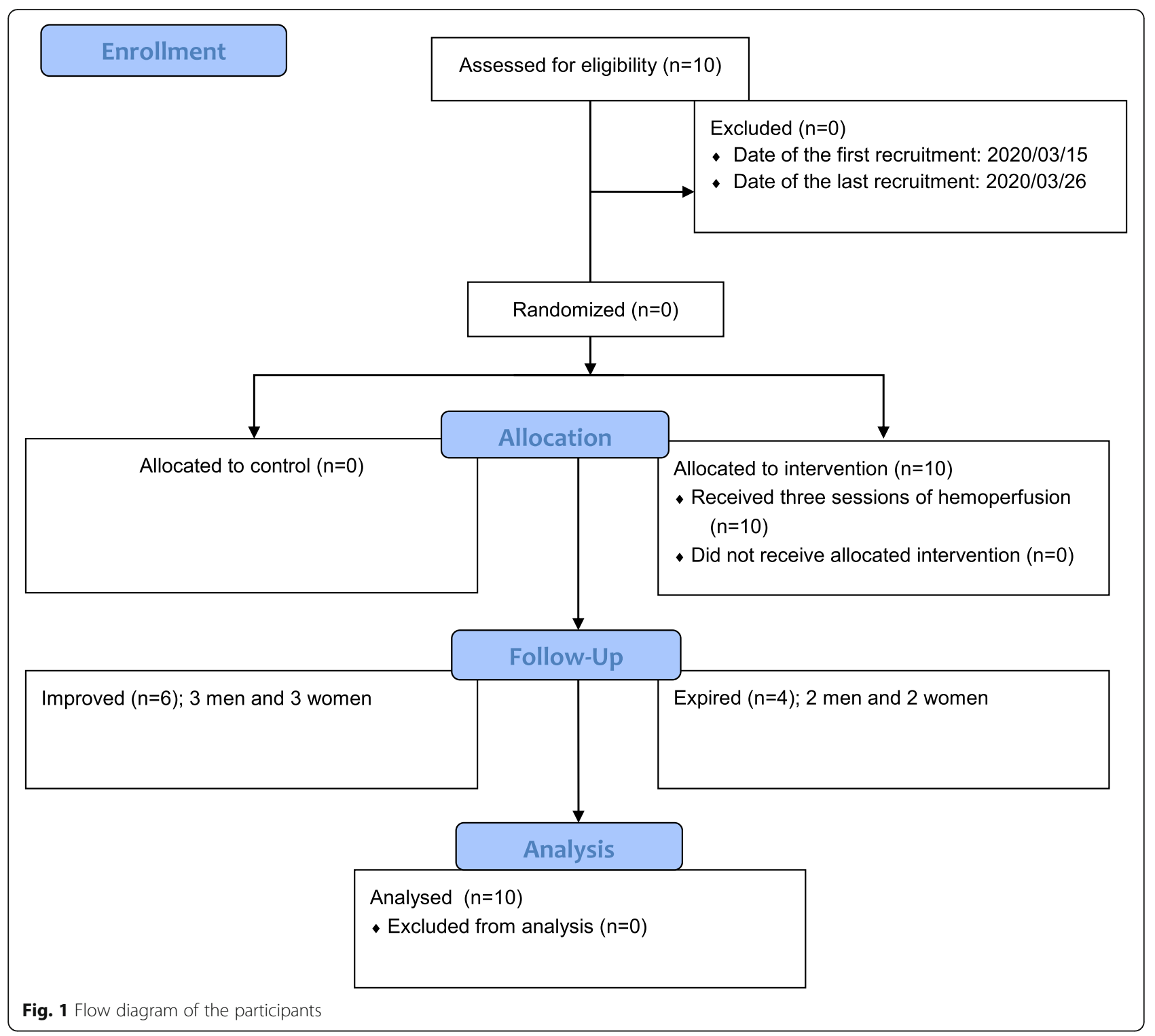

patients with severe corona virus disease [7, 9-11]. It seems that the improvement of peripheral capillary oxygen saturation during the blood purification is related to cytokine clearance rather than reduction in volume load; because during the CRRT procedure we adjusted the fluid outflow from the patient as the same amount of the fluid input. Cytokine removal following extracorporeal therapies could prevent cytokine-induced organ damages [10]; and patients who underwent these therapeutic approaches in early phase of cytokine storm could have better clinical outcomes [11].

Interleukin- 6 has been presented as a potential marker of disease severity in coronavirus infected patients. The upper limit point of serum IL-6 level in COVID-19 patients who had no severe pneumonia was reported 24.3 $\mathrm{pg} / \mathrm{mL}$, and the increased expression of IL- 6 in serum is expected to predict the severity of the COVID-19 pneumonia and a poor prognosis of patients [20]. Creactive protein (CRP) is a biomarker which may increase at early stages of coronavirus disease, and higher value of this marker can be associated with more severe pulmonary lesions in these patients [21]. In our research CRP showed a significant reduction after the intervention; and serum IL-6 decreased, although this reduction was not statistically significant. In addition to, in this study, the patients who expired showed a lower plasma lymphocytes count. Some previous studies demonstrated that COVID-19 patients with severe disease might have lower lymphocyte count compared to the mild ones [22, 23]. As we mentioned above, extracorporeal blood purification treatment can effectively remove IL- 6 , IL- 8 , IL- $1 \beta$, TNF- $\alpha$ and so on [13], however, due to the expenditures associated with measuring various inflammatory cytokines as 


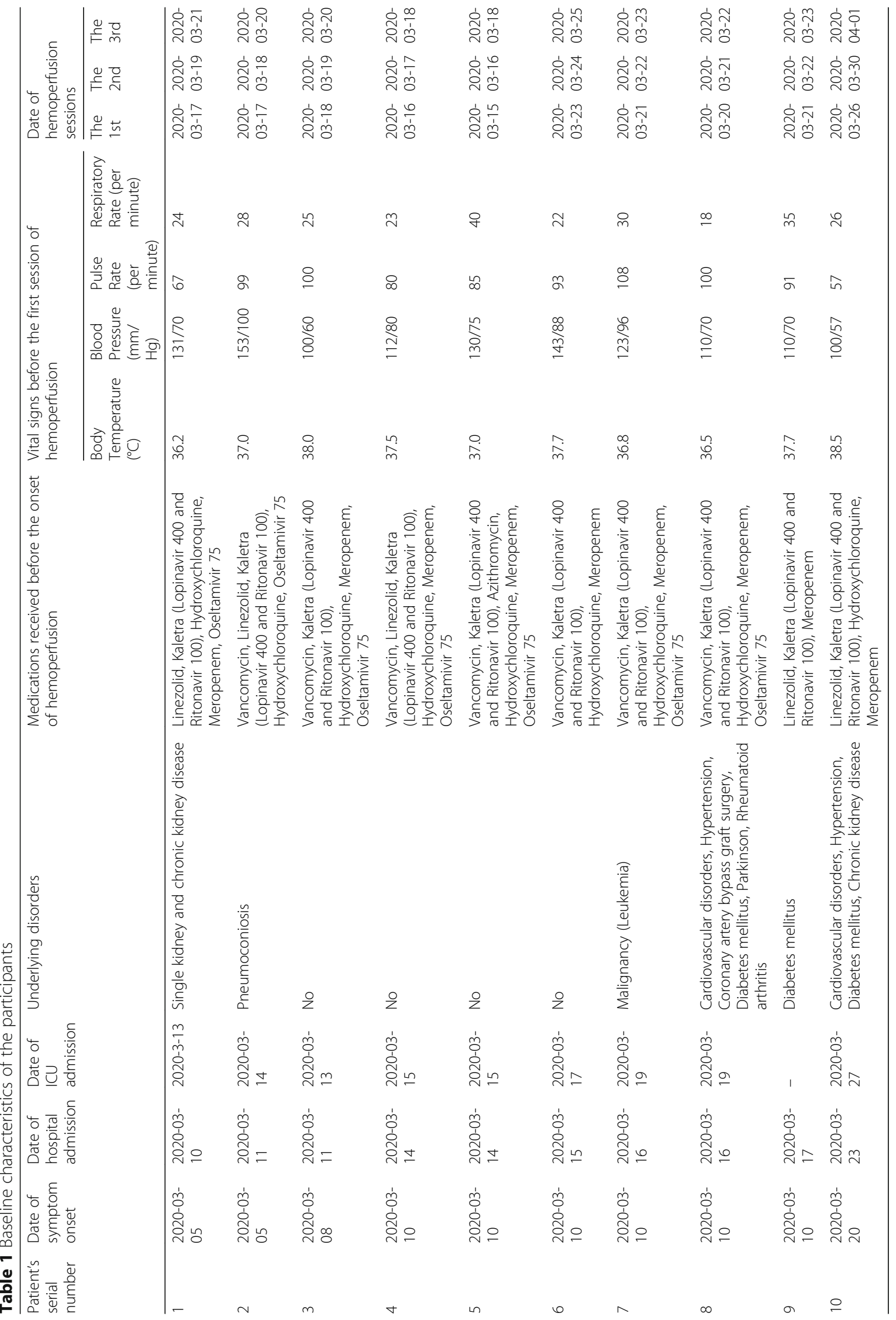


Asgharpour et al. BMC Nephrology (2020) 21:356

Page 6 of 10

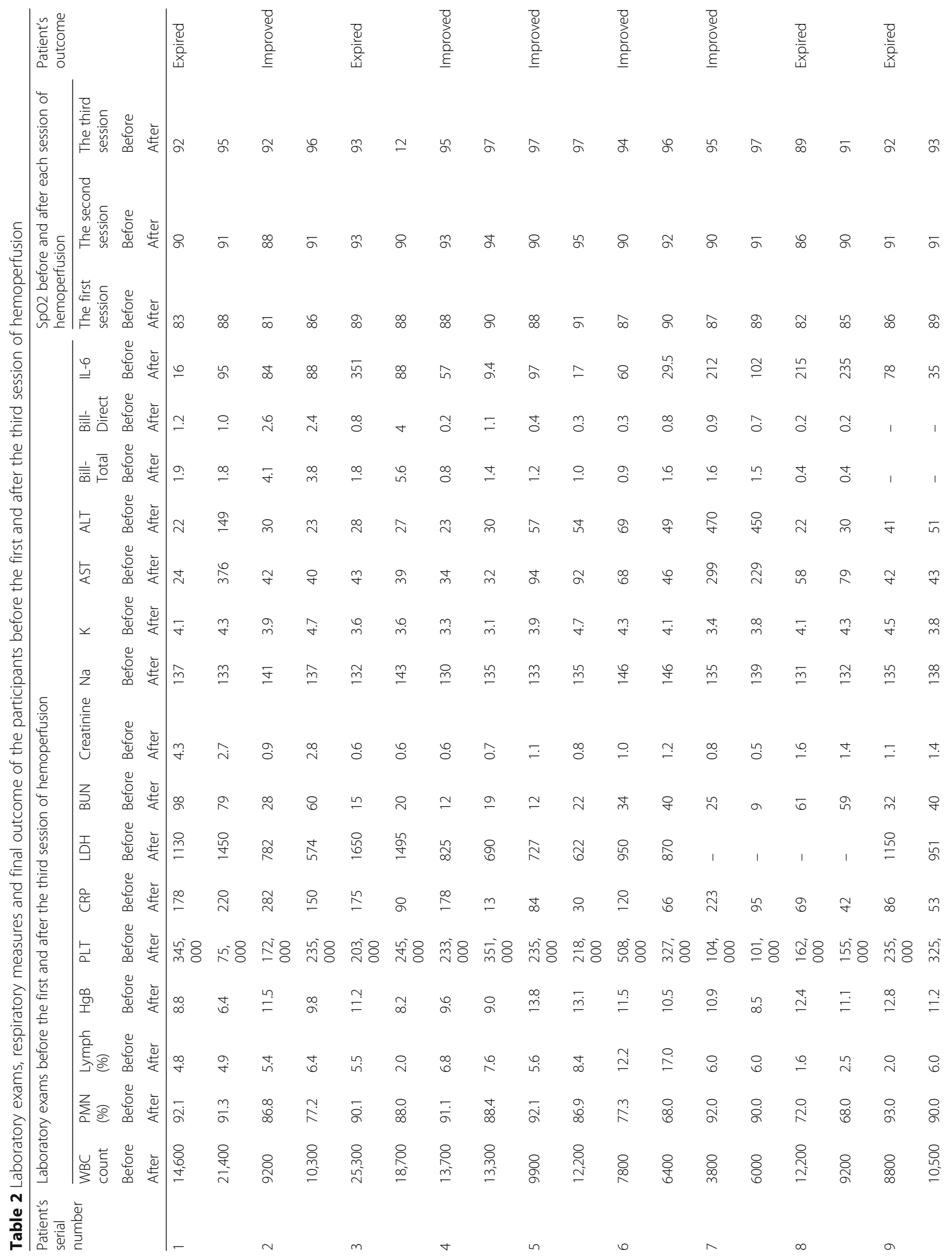




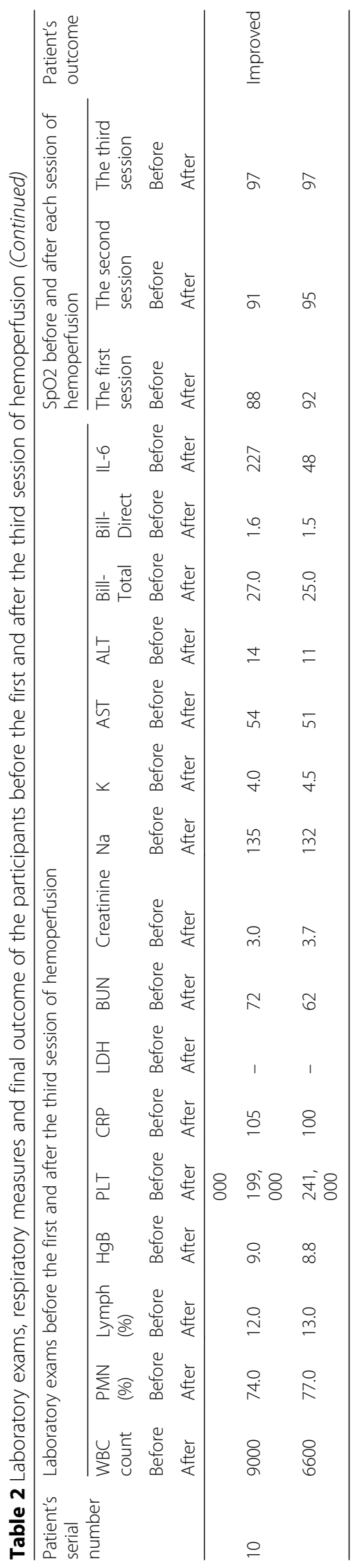


Table 3 Comparison of laboratory measures between the two improved and non-improved groups undergoing the study intervention

\begin{tabular}{llll}
\hline Variable & Improved patients $(\boldsymbol{N}=6)$ & Non-improved patients $(\boldsymbol{N}=4)$ & $\boldsymbol{p}$-value $(\mathrm{t}$-test $)$ \\
\hline Mean age $($ year) & $55.33 \pm 21.38$ & $60.25 \pm 14.10$ & 0.699 \\
Baseline white blood cell count $\left(\times 10^{9} / \mathrm{L}\right)$ & $8900.00 \pm 3204.99$ & $15,225.00 \pm 7125.71$ & 0.088 \\
Baseline percentage of plasma lymphocytes $(\%)$ & $8.90 \pm 3.58$ & $3.48 \pm 1.96$ & 0.038 \\
Serum hemoglobin $(\mathrm{mg} / \mathrm{dL})$ & $11.05 \pm 1.69$ & $11.30 \pm 1.80$ & 0.829 \\
Serum platelet count $\left(\times 10^{9} / \mathrm{L}\right)$ & $241,833.33 \pm 139,053.11$ & $236,250.00 \pm 78,415.03$ & 0.944 \\
Serum c-reactive protein $(\mathrm{mg} / \mathrm{L})$ & $152.00 \pm 100.07$ & $110.00 \pm 56.93$ & 0.538 \\
Serum lactate dehydrogenase $(\mathrm{U} / \mathrm{L})$ & $819.67 \pm 116.17$ & $1400.00 \pm 353.55$ & 0.066 \\
Blood urea nitrogen $(\mathrm{mg} / \mathrm{dL})$ & $30.50 \pm 22.16$ & $51.50 \pm 36.35$ & 0.284 \\
Serum creatinine $(\mathrm{mg} / \mathrm{dL})$ & $1.23 \pm 0.88$ & $1.90 \pm 1.65$ & 0.425 \\
Serum aspartate aminotransferase $(\mathrm{SGOT})(\mathrm{U} / \mathrm{L})$ & $68.00 \pm 26.00$ & $41.75 \pm 13.91$ & 0.141 \\
Serum alanine aminotransferase $(\mathrm{SGPT})(\mathrm{U} / \mathrm{L})$ & $52.00 \pm 19.97$ & $28.25 \pm 8.96$ & 0.083 \\
Serum IL-6 $(\mathrm{ng} / \mathrm{mL})$ & $122.83 \pm 76.49$ & $165.00 \pm 149.29$ & $0.568^{*}$ \\
\hline
\end{tabular}

*Mann-Whitney test

well as the unavailability of some laboratory kits in initial and peak periods of COVID-19 epidemic in Iran, and considering the interleukin 6 as one of the most important inflammatory cytokines, only this cytokine has been measured in this research.

In this study half of the six patients who had a chronic underlying disorder improved after the intervention. In a research in China in which 1590 laboratory-confirmed hospitalized patients with COVID-19 were evaluated about the comorbidities, hypertension and diabetes mellitus have been reported as the most prevalent comorbidities; and nearly $8 \%$ of the individuals had two or more underlying disorders [22]. A systematic review and meta-analysis reported hypertension, cardiovascular diseases, diabetes mellitus, smoking, chronic obstructive pulmonary disease, malignancy, and chronic kidney disease as the most prevalent underlying diseases among hospitalized COVID-19 patients [24]. These risk factors might compromise and deteriorate the patients' clinical outcome. Based on our results, it seems that

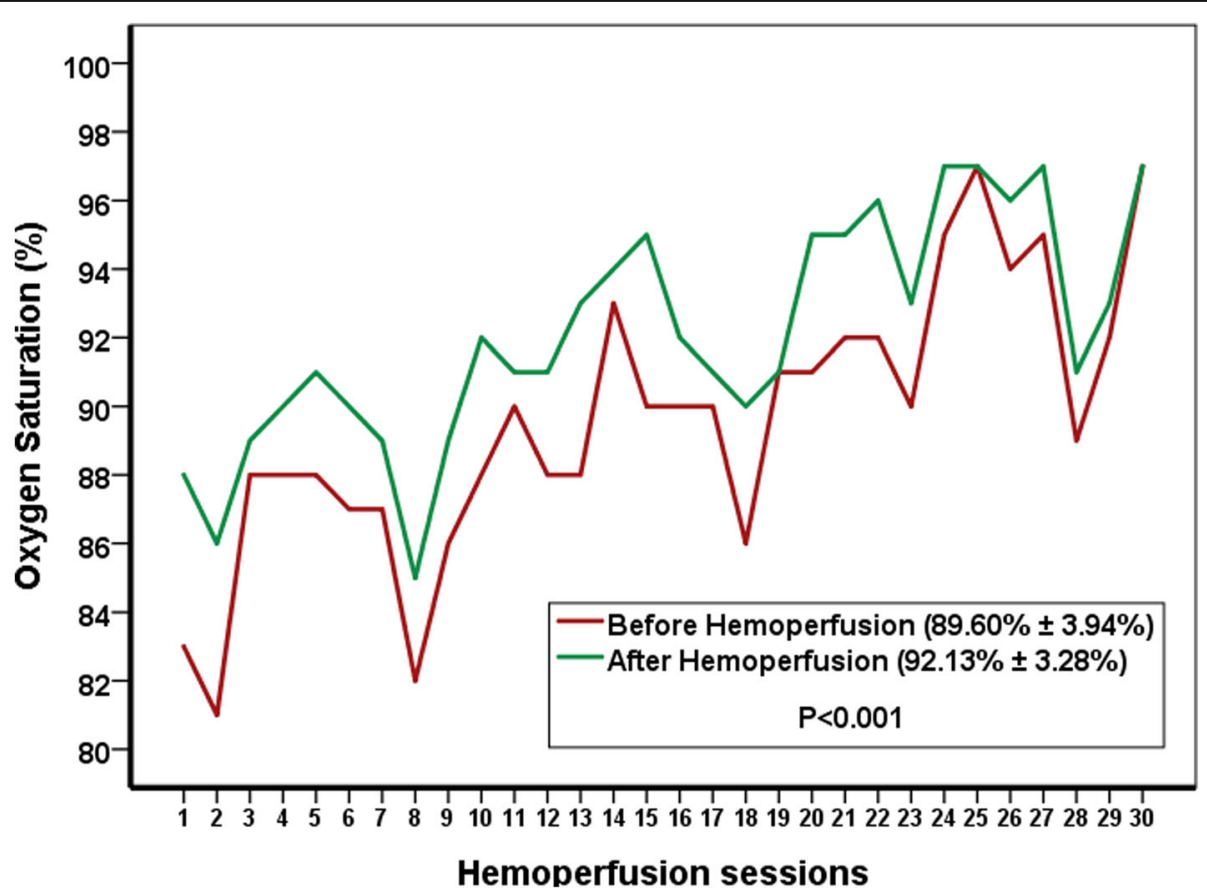

Fig. 2 Peripheral capillary oxygen saturations before and after thirty sessions of hemoperfusion in ten patients 
hemoperfusion can be beneficial in management of fluid overload, metabolic disorder, and cardiovascular dysfunction, besides to reduction of inflammatory mediators; as was mentioned in previous studies [25].

Cartridges which are used in hemoperfusion process are divided in selective and non-selective types. The Jafron resin hemoperfusion cartridges are classified as nonselective group. These cartridges are different based on the pore size distribution which determines their cutoff points for adsorption of different materials, and makes them applicable for different clinical outputs; for example HA-130 was used for improvement of uremic symptoms in chronic hemodialysis and HA-330 was effective on modulation of severe inflammatory processes [12]. We used HA-280 and HA-230 cartridges because we did not have access to other types like cytosorb, Jafron HA-380, and HA-330 in our country. There is a limited scientific evidence about the application of HA-280 and HA-230 cartridges in clinical settings [26, 27]. Previous study in which the efficacy of HA-330 resin-directed hemoperfusion has been assessed in acute respiratory distress syndrome, some considerable treatment outcomes including improved oxygenation, reduction in lung edema and histopathological signs of acute respiratory distress syndrome, and reduced circulating and alveolar cytokine levels have been resulted; and the authors concluded that this cartridge could beneficially influence the course of acute respiratory distress syndrome by attenuating systemic and pulmonary inflammatory cytokines [12]. As the cartridges we used in the process of CRRT can act as nonselective ones to absorb inflammatory cytokines such as IL-6, by conducting hemoperfusion with a mode of $\mathrm{CVVH}$, more cytokines are expected to be absorbed compared to CVVH only.

Randomized trial data about the effectiveness of hemoperfusion in COVID-19 patients is lacking, however, evidence shows that this therapeutic approach is tolerable to most patients if conducted with the assistance of nephrology specialists, in order to minimize risks of infection and bleeding [11].

The strength points of this study were well-defined condition of the patients and team-working of a multidisciplinary group of experts to conduct the intervention. The most important limitations of this research were absence of a control group, small sample size of the study population, and not to present fluid balance measures in patients. Some evidence recommends $\mathrm{PaO} 2 / \mathrm{FIO} 2(\mathrm{P} / \mathrm{F})$, rather than oxygen saturation, as the best marker of oxygenation in patients with acute respiratory distress syndrome [28]; since this study was performed during the first weeks of the onset of COVID-19 epidemic, when a large number of patients were hospitalized in the state hospital, this variable was not measured.
In addition to, it is recommended to compare the impact of hemoperfusion plus CRRT on the removal of inflammatory cytokines with the effect of hemoperfusion alone in future studies. Large prospective multicenter trials in carefully selected patients are needed to definitely evaluate the efficacy of hemoadsorption in COVID19 patients.

\section{Conclusion}

Three sessions of extracorporeal resin-directed hemoadsorption could improve the peripheral capillary oxygen saturation in six of the ten patients with severe COVID19 disease. Serum level of interleukin-6, as the secondary outcome of the study, decreased after the intervention, although this reduction was not statistically significant.

\section{Abbreviations \\ COVID-19: Corona virus disease 2019; IL-6: Interleukin-6; SpO2: Peripheral capillary oxygen saturation; PaO2: Partial pressure of oxygen in alveoli; CRP: C-reactive protein}

\section{Acknowledgements \\ Hereby, the financial support of Babol University of Medical Sciences is appreciated.}

\section{Authors' contributions \\ M.A. and H.M. contributed to conception and design, acquisition of data, analysis and interpretation of data. M.B, M.S.H.Z, S.H.H and R.A. contributed to acquisition of data. R.G. contributed to initiation of the research. A.B. contributed to analysis and interpretation of data. S.M. contributed to drafting the article and revising it critically for important intellectual content. All authors have read and approved the final version of the manuscript. \\ Funding \\ The authors declare receipt of the financial support ([2020] No.724132940) for this research from Babol University of Medical Sciences, Babol, Iran. The funder supported the initiation of this study and organization of a multidisciplinary team for conducting the intervention.}

\section{Availability of data and materials}

Data supporting the results reported in the article can be found by academic researches via sending an email to the corresponding author at $\mathrm{dr}$. mouodi@gmail.com.

\section{Ethics approval and consent to participate}

This research has been approved by the Ethics Committee of Babol University of Medical Sciences with the approval code

IR.MUBABOL.HRI.REC.1399.038. Also, the research protocol has been registered in the website of Iranian Registry of Clinical Trials with the reference number IRCT20150704023055N2. A written informed consent was obtained from all participants or their proxies.

\section{Consent for publication}

All participants or their proxies gave written consent for their personal or clinical details along with any identifying images to be published in this study.

\section{Competing interests}

The authors declare that they have no competing interests.

\section{Author details}

${ }^{1}$ Department of Internal Medicine, Rouhani Hospital, Babol University of Medical Sciences, Babol, Iran. ${ }^{2}$ Infectious Diseases and Tropical Medicine Research Center, Health Research Institute, Babol University of Medical Sciences, Babol, Iran. ${ }^{3}$ Department of Anesthesiology, School of Medicine, Babol University of Medical Sciences, Babol, Iran. ${ }^{4}$ Department of Internal Medicine, Babol University of Medical Sciences, Babol, Iran. ${ }^{5}$ Social 
Determinants of Health Research Center, Health Research Institute, Babol University of Medical Sciences, Ganjafrooz Street, Babol, Iran.

Received: 11 May 2020 Accepted: 13 August 2020

Published online: 20 August 2020

\section{References}

1. World Health Organization. Coronavirus health topics: World Health Organization; 2020. Available from: https://www.who.int/health-topics/ coronavirus.

2. Rothan HA, Byrareddy SN. The epidemiology and pathogenesis of coronavirus disease (COVID-19) outbreak. J Autoimmun. 2020;26:102433. https://doi.org/10.1016/j.jaut.2020.102433.

3. Chan KW, Wong VT, Tang SCW. COVID-19: an update on the epidemiological, clinical, preventive and therapeutic evidence and guidelines of integrative Chinese-Western medicine for the management of 2019 novel Coronavirus disease. Am J Chin Med. 2020;13:1-26.

4. World Health Organization. Coronavirus disease 2019 (COVID-19) situation report. 2020. Contract No: 96 . Data as received by WHO from national authorities by 10:00 CEST, 25 April 2020. Available from: https://www.who. int/docs/default-source/coronaviruse/situation-reports/20200425-sitrep-96covid-19.pdf?sfvrsn=a33836bb 2 .

5. Cascella M, Rajnik M, Cuomo A, Dulebohn SC, Napoli RD. Features, evaluation and treatment Coronavirus (COVID-19); 2020.

6. Huang C, Wang Y, Li X, Ren L, Zhao J, Hu Y, et al. Clinical features of patients infected with 2019 novel coronavirus in Wuhan, China. Lancet. 2020;395(10223):497-506

7. Schadler D, Pausch C, Heise D, Meier-Hellmann A, Brederlau J, Weiler N, et al. The effect of a novel extracorporeal cytokine hemoadsorption device on IL-6 elimination in septic patients: a randomized controlled trial. PLoS One. 2017;12(10):e0187015

8. Naicker S, Yang C-W, Hwang S-J, Liu B-C, Chen J-H, Jha V. The Novel Coronavirus 2019 epidemic and kidneys. Kidney Int. 2020;97:824-8. https:// doi.org/10.1016/j.kint.2020.03.001.

9. Monard C, Rimmele T, Ronco C. Extracorporeal blood purification therapies for Sepsis. Blood Purif. 2019;47(Suppl 3):1-14.

10. Ronco C, Reis, T. Kidney involvement in COVID-19 and rationale for extracorporeal therapies. Nat Rev Nephrol. 2020;16:308-10. https://doi.org/ 10.1038/s41581-020-0284-7.

11. Ma J, Xia P, Zhou Y, Liu Z, Zhou X, Wang J, et al. Potential effect of blood purification therapy in reducing cytokine storm as a late complication of critically ill COVID-19. Clin Immunol. 2020;214:108408.

12. Honoré PM, De Bels D, Barreto Gutierrez L, Spapen HD. Hemoadsorption therapy in the critically ill: solid base but clinical haze. Ann Intensive Care. 2019;9(1):22

13. Harm S, Schildbock C, Hartmann J. Cytokine removal in extracorporeal blood purification: an in vitro study. Blood Purif. 2020;49(1-2):33-43.

14. Kellum JA, Bellomo R, Ronco C. Continuous renal replacement therapy. In: JA Kellum, editor. Pittsburgh Critical Care Medicine. Second ed. Oxford University Press; 2016. https://doi.org/10.1093/med/9780190225537.001. 0001.

15. Argani H, Alirezaei A, Ghorbanihaghjo A, Azizi T, Asgharpour M, et al. Comparing the serum levels of Adipocytokines in the renal transplant recipients and healthy individuals: a case-control study. Iran Red Crescent Med J. 2018;20(3):e62674. https://doi.org/10.5812/ircmj.62674.

16. Epstein SK. Weaning from mechanical ventilation: Readiness testing. In: Parsons PE, Finlay G, editor. 2018. Available from: https://www.uptodate. com/contents/weaning-from-mechanical-ventilation-readinesstesting\#subscribe. Last updated: Dec 04, 2018.

17. Ye Q, Wang B, Mao J. The pathogenesis and treatment of the 'cytokine Storm' in COVID-19. J Inf Secur. 2020;80(6):607-13.

18. Mehta P, McAuley DF, Brown M, Sanchez E, Tattersall RS, Manson JJ. COVID19: consider cytokine storm syndromes and immunosuppression. Lancet. 2020;395(10229):1033-4.

19. Zhang C, Wu Z, Li JW, Zhao H, Wang GQ. The cytokine release syndrome (CRS) of severe COVID-19 and Interleukin-6 receptor (IL-6R) antagonist Tocilizumab may be the key to reduce the mortality. Int J Antimicrob Agents. 2020;105954:2020.

20. Russell B, Moss C, George G, Santaolalla A, Cope A, Papa S, et al. Associations between immune-suppressive and stimulating drugs and novel
COVID-19-a systematic review of current evidence. Ecancermedicalscience. 2020;14:1022.

21. Wang L. C-reactive protein levels in the early stage of COVID-19. Med Mal Infect. 2020;50(4):332-4.

22. Guan W-J, Liang W-H, Zhao Y, Liang H-R, Chen Z-S, Li Y-M, et al. Comorbidity and its impact on 1590 patients with Covid-19 in China: a Nationwide analysis. Eur Respir J. 2020;55:2000547.

23. Guo $Y-R$, Cao Q-D, Hong Z-S, Tan Y-Y, Chen S-D, Jin H-J, et al. The origin, transmission and clinical therapies on coronavirus disease 2019 (COVID-19) outbreak - an update on the status. Mil Med Res. 2020;7(1):11.

24. Emami A, Javanmardi F, Pirbonyeh N, Akbari A. Prevalence of Underlying Diseases in Hospitalized Patients with COVID-19: A Systematic Review and Meta-Analysis. Arch Acad Emerg Med. 2020;8(1):e35 e.

25. Zhang $Y, Y u L$, Tang $L$, Zhu $M$, Jin $Y$, Wang $Z$, et al. A promising anticytokine-storm targeted therapy for COVID-19: the artificial-liver bloodpurification system. Engineering (Beijing). 2020. https://doi.org/10.1016/j.eng 2020.03.006.

26. Garg SK, Goyal PK, Kumar R, Juneja D, Bhasin A, Singh O. Management of life-threatening calcium channel blocker overdose with continuous venovenous hemodiafiltration with charcoal hemoperfusion. Indian J Crit Care Med. 2014;18(6):399-401. https://doi.org/10.4103/0972-5229.133939.

27. Juneja D, Singh O, Bhasin A, Gupta M, Saxena S, Chaturvedi A. Severe suicidal digoxin toxicity managed with resin hemoperfusion: a case report. Indian J Crit Care Med. 2012;16(4):231-3. https://doi.org/10.4103/0972-5229. 106511

28. Griffiths MJD, McAuley DF, Perkins GD, Barrett N, Blackwood B, Boyle A, et al. Guidelines on the management of acute respiratory distress syndrome. BMJ Open Respir Res. 2019;6(1):e000420 e.

\section{Publisher's Note}

Springer Nature remains neutral with regard to jurisdictional claims in published maps and institutional affiliations.

Ready to submit your research? Choose BMC and benefit from:

- fast, convenient online submission

- thorough peer review by experienced researchers in your field

- rapid publication on acceptance

- support for research data, including large and complex data types

- gold Open Access which fosters wider collaboration and increased citations

- maximum visibility for your research: over $100 \mathrm{M}$ website views per year

At BMC, research is always in progress.

Learn more biomedcentral.com/submission 